\title{
АРХІВОЗНАВСТВО
}

UDC 930.22

DOI: doi.org/10.21272/shaj.2018.i31.p.5

\author{
VALENTYNA V. BEZDRABKO \\ Dr (History), Professor, Kyiv National University of Culture and Arts (Ukraine)
}

\section{ARCHIVE EDUCATION IN UKRAINE: STATE AND PROSPECTS}

\begin{abstract}
The importance of understanding the goal of reforming archival education was noted, as well as solving the related tasks that will become the basis for its successful implementation. Currently, archives do not need a "universal amateur", but deeply knowledgeable with the archival technologies specialist, who is capable of working with traditional documents of any era and a variety of external and internal characteristics, as well as being able to orient at the user and researcher level with the peculiarities of the functioning of information in the eenvironment, by working effectively with information technologies. Requirements to the skills of the archivist are not frozen and constantly changing according to the call of time. Defining the scope of the skills of the archivist is the beginning of who he should be, for a long time or not.

The professionalism of the archivist needs a proper "infrastructure" that dialectically influences and determines its level. It is about modern material and technical support of the branch and financial support from any sources of a wide range of activity of archival institutions and their labor resources. This requires a responsible attitude of the state, society to the archives, development of inter-institutional productive dialogue of all involved in the training of archivists, archives, public associations, professional associations, in general, support of professional communication, etc. Material, technical and financial sectoral resources are the second powerful condition for reforming archival education. All plans to transform the archival education and to fill it with new content may also be impracticable without the appropriate legal and regulatory framework for educational activities.

An important condition for the successful reformation of archival education in Ukraine is the personnel, that is, those who can attract and use various economic, technical, technological, scientific, informational, communicative-strategic resources in order to solve the urgent problems of the industry. Reforms should also be carried out by professionals, who are capable not only of producing ideas, but also of decisive anti-crisis management actions oriented towards positive results and achievement of goals.

It was emphasized that without systematic management and various (social, material, financial, technical) support at the state level, in the first place for the employee of the archival institution is difficult to achieve the desired result.

The prospects of archival education in multidimensional, varied educational programs in higher education, which tend to classical academies and technological practices, postgraduate education, distant form of organization of internships, retraining of personnel, a productive union of educational institutions and archival institutions, professional communication and managers, who capable of providing reform processes at different levels.
\end{abstract}

Keywords: Archival Education, Archivist, Archive, University, Education, the Concept of Archival Education.

БЕЗДРАБКО В.В.

Доктор історичних наук, професор, Київський національний університет культури і мистецтв (Україна)

\section{АРХІВНА ОСВІТА В УКРАЇНI: СТАН І ПЕРСПЕКТИВИ}

Анотація. Стаття присвячена сучасному стану архівної освіти в Украӥні та перспективам ї̈ розвитку. Для успішної реалізачії мети розвідки було залучено до розгляду офіцуійні джерела нормативно-правового регулювання вищої освіти в Украӥні, проект 
концепції розвитку архівної освіти 1998 р. та статистичні дані изьогорічної вступної кампанії. Це дало змогу об'єктивно оцінити сучасний стан галузевої освіти та можливі иляхи розв'язання проблем для створення умов позитивної динаміки ї̈ розвитку. Окремо зауважено на умовах успішної реалізації реформи архівної освіти, необхідності залучення передового зарубіжного досвіду та збереженні національних традицій ї̈ розвитку в Україні.

Ключові слова: архівна освіта, архівіст, архів, вища школа, освіта, концепція архівної освіти.

\section{БЕЗДРАБКО В.В.}

Доктор исторических наук, профессор, Киевский национальный университет культуры и искусств (Украина)

\section{АРХИВНОЕ ОБРАЗОВАНИЕ В УКРАИНЕ: СОСТОЯНИЕ И ПЕРСПЕКТИВЫ}

Аннотация. Статья посвящена современному состоянию архивного образования в Украине и перспективам его развития. Для успешной реализации цели статьи были привлечены к рассмотрению официальные источники нормативно-правового регулирования высшего образования в Украине, проект концепции развития архивного образования 1998 года, статистические данные вступительной кампании этого года. Это позволило объективно оценить современное состояние отраслевого образования и возможные пути решения проблем для создания условий положительной динамики его развития. Отдельно сказано об условиях успешной реализации реформы архивного образования, необходимости привлечения передового зарубежного опыта и сохранения нациинальных традиций его развития в Украине.

Ключевые слова: архивное образование, архивист, архив, высшая школа, образование, концепция архивного образования.

Минуло 20 років від оприлюднення науковому й широкому загалу першого (i єдиного) часів незалежної України проекту концепції підготовки та післядипломної освіти кадрів для архівних установ, авторами якого стали знані фаховим колам представники галузі - Я.С. Калакура, В.С. Лозицький, І.Б. Матяш і К.Т. Селіверстова (Матяш, 1998). Публікація стала резонансною та викликала жвавий і непідробний інтерес.

Основний зміст проекту розгортався довкола таких позицій: 1) допрофесійну підготовку здійснювати у загальноосвітній та школах нового типу, а також на молодших курсах закладів вищої освіти; 2) базову спеціальну освіту архівістів-фахівців (істориків, палеографів, археографів) організувати чи продовжити на історичних факультетах державних університетів, а також у пропонованих для відкриття регіональних науковоосвітніх центрах; 3) базову спеціальну освіту архівістів інформаційного профілю (виокремлено нами - В.Б.) - в інститутах культури на факультетах бібліотечноінформаційних систем, проте зі сміливою перспективою згодом - в окремому “самостійному спеціальному вищому навчальному закладі з підготовки кадрів для документно-комунікаційної сфери"; 4) перепідготовка та підвищення кваліфікації керівників і провідних спеціалістів архівних установ у планованому “Центрі архівної післядипломної освіти при Головархіві України”, а інших осіб - у регіональних науковоосвітніх центрах при вишах, початківців - при державних обласних архівах України (Матяш, 1998: 24). Окрім цього, з огляду на “одержавлення” статусу окремих категорій працівників архівної галузі, вищого керівного складу, пропонувалося залучити до підготовки і перепідготовки архівістів окремі заклади вищої освіти, які спеціалізувалися на підготовці держслужбовців. Ішлося, зокрема, про Національну академію державного управління при Президентові України, ії регіональні структурні підрозділи в Одесі, Львові, Харкові, та ті заклади, що готували магістрів із державного управління (Матяш, 1998: 
24). Вказані позиції проекту уточнювалися на рівні організаційних заходів і змістового наповнення архівної освіти у кожному конкретному випадку. Виокремимо з цього найважливіше - автори проекту проголошували багатовекторність архівної освіти, наполягали на іï безперервності та запропонували схему розбудови мережі освітніх центрів для підготовки й перепідготовки архівістів.

Багато сміливих пропозицій залишилися нереалізованими, проте далеко не всі. Авторські ідеї оптимістично були сприйняті архівною спільнотою, котра давно потребувала модернізації галузевої освіти. Тоді архівісти-практики та науковці-педагоги взялися за перо й започаткували дискусії на шпальтах фахової періодики щодо стану, шляхів розвитку архівної освіти в Україні, намагаючись переконати один в одного у слушності власних ідей. Упродовж найближчого часу, після 1998 р., з'явилася низка сміливих і актуальних публікацій про те, яким має бути магістральний та інші вектори галузевого освітнього розвитку короткострокової перспективи. Поряд із фундаментальними студіями з історії архівної освіти в Україні (Матяш, 2000), зросли ті, які увиразнили розмаїття поточних завдань і можливих їх розв'язків.

У 1990-х роках на багатьох університетських кафедрах історичних факультетів відкривається нова спеціалізація - “Історія, архівознавство”, здебільшого в рамках звичних підходів до підготовки історика-архівіста, апробованих за радянських часів не одним десятиріччям у стінах Московського державного історико-архівного інституту. Навчальні плани підготовки історика-архівіста увиразнювалися лише за рахунок розширених обсягів годин на спеціальні історичні дисципліни, введення окремих курсів архівознавчого циклу та незначних новаторських пропозицій, рухів у викладанні (Калакура, 2002). Значний теоретичний складник історико-архівної освіти в “класичних" університетах увиразнював їх сутність і багаторічні традиції та не відповідав мінливій природі електронно-цифрових засобів комунікації, умовам існування інформації, необхідності модернізації архівних виробничих технологій, орієнтованих на концепцію електронного архіву.

Окремо слід сказати про Київський національний університет імені Тараса Шевченка і погодитися з Я. Калакурою, М. Щербаком у тому, що кафедра архівознавства та спеціальних галузей історичної науки доволі еластично відреагувала на нові віяння часу, потреби освітнього ринку, запропонувавши модернізовані варіанти навчальних планів, започаткувавши наукові, освітні, громадські галузеві проекти, а згодом реалізувавши їх спільно з Українським науково-дослідним інститутом архівної справи та документознавства (Калакура, 2000; 2004; 2008; 2013). Ідеться про серію знакових видань для підготовки архівістів, перші в Україні за часів незалежності навчальні посібники "Нариси історії архівної справи в Україні” (2002), “Архівознавство” (2003) та “Хрестоматію з архівознавства” (2003). Із-поміж університетських старань спільно з УНДІАСД слід також відмітити підтримку ними фахової періодики, зокрема "Студій з архівної справи та документознавства”, сприяння діяльності Спілки архівістів України і багатьох інших важливих починань архівістів “родом” із рубіжних десятиліть.

Паралельно до цього доволі популярним у 1990 -х роках стало конституювання підготовки архівістів урамках не традиційної моделі освіти на “історичномугрунті”, а в межах нової навчальної спеціальності, захоплення якою з середини 1990-х років набирало обертів. Ідеться про фах “Документознавство та інформаційна діяльність”. Н. Гончарова, М. Довбищенко, В. Лозицький, Н. Маковська, В. Терно й ін. відомі подвижники спеціальності стали активними учасниками широкої наукової дискусії та поборниками виведення розуміння змісту архівної освіти на якісно інший рівень, пов'язаний з ідеями підготовки “архівістів інформаційного профілю" (Гончарова, 1999; Довбищенко, 1999; Маковська, 2002; Терно, 1998).

Провідником архівної освіти новітнього спрямування став Київський державний інститут культури (нині - Київський національний університет культури і мистецтв). 
Від 1991 р. перехідним варіантом нової спеціалізації став “архівіст-бібліограф”, підготовкою якого опікувалася кафедра історії (з 1994 р. - кафедра історії та архівознавства, а з 1998 р. - архівознавства) факультету бібліотечно-інформаційних систем. Реорганізація університету призвела до виокремлення у 1996 р. факультету документознавства та інформаційної діяльності, у рамках якого й було започатковано нову для вищої школи України навчальну спеціалізацію - “документознавець-архівіст”. У різні часи на кафедрі архівознавства працювали знані спеціалісти галузі - К.І. Климова, В.С. Лозицький, Н.В. Маковська, В.С. Шандра та ін., що забезпечувало й визначало якісний рівень підготовки документознавця-архівіста.

Із-поміж здобутків архівного університетського осередку - розроблення авторських курсів з архівної справи відповідно до навчальних планів тодішніх Московського державного історико-архівного інституту та Київського державного університету ім. Т.Г. Шевченка, їх методичне забезпечення й укладання одного з перших термінологічних словників з архівістики часів незалежної України (Короткий російськоукраїнський словник архівних термінів, 1993). I, можливо, про унікальність у викладах традиційних для фаху дисциплін на той час говорити не доводиться, проте спроби вдатися до подібного варті уваги.

Навчальні плани підготовки документознавця-архівіста балансували між двома моделями випускника вищої школи - історика-архівіста та документознавця. Саме тому здобувачам цього фаху викладалися дисципліни історико-архівознавчого $(30,5 \%$ від загального обсягу навчальних годин) та інформаційного $(35,5 \%)$ циклів (Терно, 1998). Причому, судячи із джерел, єдиної точки зору стосовно дисциплінного наповнення університетських навчальних планів для документознавця-архівіста не існувало. Тривала дискусія між опонентами відбилася на шпальтах фахової періодики. Публікації тих часів віддзеркалили різні позиції педагогів університету. Одні з них виступали за поглиблення в архівній освіті історико-архівного компонента, інші - інформаційного (Терно, 1998; Довбищенко, 1999). Проте переміг компромісний підхід, результатом якого стала, на наш погляд, майже збалансована номенклатура дисциплін навчального плану. Зміст фундаментальних і професійно-орієнтованих предметів увиразнювався вузько спеціалізованими курсами, які доповнювали підготовку фахівців (Кінофотодокументи, 1995; Архіви зарубіжних країн, 1995; Державні і відомчі архіви України, 1995; Спеціальні історичні дисципліни, 1994; Археографія, 1995; Історія і організація архівної справи, 1998; Історія і організація діловодства, 1992), а програми виробничої практики гармонійно збагачували їх (Створення документів та організація роботи з ними, 1997; Архівні технології, 1997; Економіка і менеджмент в архівній справі, 2000). Причому базами проведення практики, згідно з угодою підписаною між університетом і центральним органом виконавчої влади архівної галузі, стали державні архіви Києва.

Почин столичного університетукультури і мистецтв підхопили й інші подібного профілю виші (Терно, 1998). Сміливі експерименти не відзначались послідовністю, наполегливістю та системністю і, зрештою, до середини 2000 -х років призвели до відмови від підготовки архівістів у межах спеціальності “Документознавство та інформаційна діяльність”. Навряд чи можна було самотужки одному чи декільком навчальним закладам вирішити глобальні проблеми реформування архівної освіти в Україні. Історичні факультети університетів переважно обмежилися архівознавчим “мінімальним мінімумом", класичним набором спеціальних галузей історичної науки для архівістів, а на осучаснення навчальних планів, написання відповідних підручників, посібників у руслі загальносвітових тенденцій розвитку архівістики, а отже, й архівної освіти годі було сподіватися. Погодьмося з висновком Н. Маковської, безпосереднім учасником тих подій, “класичні” університети продовжили готувати істориків, а виші галузі культури запропонували студентам опановувати фах 
документознавця, із додатковим набором дисциплін, що легітимізував в обох випадках додаток до назви основної частини спеціалізації - “архівіст” (Маковська, 2002: 50).

Останнім важливим здобутком початку 2000 -х років вважаємо відкриття наукової спеціальності “Документознавство, архівознавство” спочатку в системі історичних наук, а згодом - соціальних комунікацій. Це уможливило підготовку кадрів вищого гатунку для архівної галузі. Та насправді констатуємо обмаль їі представників, які скористалися цією можливістю і здобули відповідний рівень кваліфікації (Корнєєв, 2016).

Отож, підсумовуючи результати перших десятиріч розбудови архівної освіти в Україні, зазначимо, що багато декларованих і правильних ідей, виголошених із трибун конференц-залів, оприлюднених на шпальтах наукових фахових видань, залишилися нереалізованими з різних причин. Ми можемо говорити про хронічне недофінансування архівної сфери, недостатній інтерес держави й очільників архівної галузі до фахової освіти, популістський характер багатьох освітніх проектів і декларативність більшості програм розвитку архівної справи в Україні без їх підтримки і умов для тактично виваженої реалізації, безкінечні й непослідовні реформи загалом вищої освіти, відсутність окремої навчальної спеціальності з архівознавства до 2015 р., кадровий “голод”, стереотипний імідж архівіста, консервативні підходи до змісту архівної освіти на рівні навчальних закладів, малу обізнаність науково-педагогічних кадрів із тенденціями зарубіжної архівістики та освіти, безініціативність чи малу активність громадських професійних об'єднань, низьку академічну мобільність викладачів вищої школи, причетних до освіти архівістів, відсутність попиту на професію 3-поміж молоді, нерозробленість оптимальної сучасної моделі професійної галузевої освіти з необхідними умовами для іiї адаптації та модифікації, інші об'єктивні й суб'єктивні чинники, пов'язані з базовими, інфраструктурними складовими системи під назвою “архівна освіта".

Утім найголовнішим, на нашу думку, є знівельоване радянськими часами ставлення суспільства й держави до архівів, галузі загалом, відсутність усвідомлення значущості збереження “слідів” життя індивіда, людства у глобальному масштабі. Емоційні заклики колег на тлі тривалого пробуксовування перебудови архівної освіти про те, аби змінити нарешті ставлення до архівіста як представника сфери обслуговування замовників $\mathrm{i}$ споживачів, а відтак і переосмислити його місію через переформатування освіти залишаються актуальними й донині (Маковська, 2002: 53; Хорхордина, 2001: 267).

2015 р. започаткував новий етап в історії архівної освіти в Україні. Ідеться про затвердження постановою Кабінету Міністрів України № 266 від 29 квітня 2015 р. модернізованого переліку галузей знань і навчальних спеціальностей, за якими має здійснюватися підготовка здобувачів вищої освіти (Про затвердження переліку галузей знань і спеціальностей, за якими здійснюється підготовка здобувачів вищої освіти, 2015). Згідно зі згаданою постановою, “архівна справа”, як об' єкт освітньої діяльності, нарешті отримала реєстрацію в переліку навчальних спеціальностей під шифром 029 “Інформаційна, бібліотечна та архівна справа". Вживання при формулюванні спеціальності 029 означника в однині - “справа”, додатково вказує на те, що авторами такої назви напряму підготовки інформаційна, бібліотечна й архівна діяльності вочевидь сприймаються як єдина справа. Це викликало у фахівців непідробну незгоду. Суть заперечень криється, передусім, у некоректному формулюванні назви спеціальності, коли через кому поєднуються поняття різного порядку: сфери професійної діяльності (архів, бібліотека) та іiі вид (інформаційна). Погодьмося з очевидним твердженням, що інформаційна діяльність є невід’ємною ланкою роботи архівістів чи бібліотекарів. Тож питання, про яку “інформаційну справу” йдеться в назві, i, що дуже важливо - сферу їі практики, так само, як і тлумачення змісту цього словосполучення, наразі залишаються відкритими. При цьому чітко визначено коло “суміжних” професійних занять - 
інформаційне та бібліотечне. Донині вони існували в межах інших спеціальностей “Документознавство та інформаційна діяльність" i "Книгознавство, бібліотекознавство та бібліографознавство". А от стосовно архівного складника, то з 1990-х років він залишався "загубленим" в історичних спеціальностях, а згодом ненадовго оприсутнився в соціокомунікаційній галузі знань. Виняток складає кафедра архівознавства та спеціальних галузей історичної науки Київського національного університету імені Тараса Шевченка, яка традиційно виступає за розбудову архівної освіти в Україні.

Адепти подібного формулювання апелюють до зарубіжного досвіду фіксування архівної та бібліотечної “справи” в межах єдиної спеціальності, ігноруючиприцьомуобставинипоходження такого підходу, що суттєво відрізняються від вітчизняної, а ширше - європейської практик, про що ми вже неодноразово писали (Бездрабко, 2017). До того ж, у міжнародному варіанті вживання прикметників “інформаційні”, “бібліотечні”, “архівні” стосується означуваного поняття “науки”/ “студіï”, а не “справа”, і в цьому також полягає сугтєва відмінність.

Незважаючи на подібний формат, напрями підготовки архівістів і бібліотекарів у зарубіжній практиці існують автономно й базуються на різних бакалаврських, магістерських програмах, які перегукуються між собою на рівні деяких спільних дисциплін. Розуміння відмінностей, специфіки діяльності архівістів і бібліотекарів зафіксовано також і в міжнародному класифікаторі професій International Standard Classification of Occupations 2008. Так, архівісти об'єднані в професійній групі - “Archivists and curators” (“Архівісти і зберігачі”, індекс 2621), а бібліотекарі і з ними пов”язані фахівці інформаційної галузі - в "Librarians and related information professionals" (“Бібліотекарі та пов'язані з ними фахівці інформаційної галузі”, індекс 2622) (International Standard Classification of Occupations 2008, 85). Разом вони утворюють професійну групу 262 "Librarians, archivists and curators" ("Бібліотекарі, архівісти та зберігачі") (International Standard Classification of Occupations 2008, 85). Загалом, з урахуванням інформатизації усіх сфер життя сучасного суспільства, можна погодитися на подібні трансформації (навіть із некоректним формулюванням у назві), оскільки за цим ідеться про підготовку архівіста, здатного працювати з інформацією та документами в електронному форматі.

Відмітимо також, що зарубіжний досвід сформував у середині минулого століття оптимальну модель поєднання архівної освіти 3 підготовкою керуючих документаційними процесами, базовану на платформі ідей Т.Р. Шелленберга, якої й дотримуються донині. Тому більшість освітніх програм за кордоном мають назву “Архіви й керування документаційними процесами", або ж варіації на кшталт цього.

Нині на рівні проектів стандартів бакалаврів, магістрів зі спеціальності 029 "Інформаційна, бібліотечна та архівна справа" штучно змодельовано простір без урахування основоположних засад розвитку архівної освіти та за відсугності чітко означених спеціальних компетентностей, необхідних для фаху архівіста (Проекти стандартів вищої освіти, 2016). Неодноразові намагання небайдужих, зокрема Спілки архівістів України, провідної спеціалізованої кафедри Київського національного університету імені Тараса Шевченка, вплинути на ситуацію не мали успіху, а їхні пропозиції не взяті до уваги шанованою науковометодичною комісією при Міністерстві освіти і науки України, яка би мала навпаки опікуватися користю для спільної справи. На маргінесі професійних інтересів архівна освіта залишилася також у проекті стандарту 032 “Історія та археологія" (бакалавр, магістр) (Проекти стандартів вищої освіти, 2016). Питання підготовки кадрів вищої кваліфікації залишається відкритим і нерозв'язаним у площині формування сучасного нормативноправового поля ііі розбудови, що накладає відбиток і на зміст типових навчальних планів, номенклатуру дисциплін, їх тематичне наповнення тощо.

Саме за таких умов, починаючи від 2016 р., відбуваються в Україні вступні кампанії абітурієнтів до вишів на спеціальність 029 “Інформаційна, бібліотечна та архівна справа”. 
I хоча пройшло обмаль часу, проте варто поділитися першими спостереженнями за динамікою розвитку спеціальності та наскільки вона є оптимістичною.

Відразу вкажемо на існування об'єктивних і суб'єктивних умов протікання вступних кампаній, які визначають їх. Ідеться про негативні тенденції економічного розвитку, особливості демографічної ситуації в Україні, погіршення рівня підготовки випускника загальноосвітніх навчальних закладів, надмірну пропозицію освітніх послуг в Україні і доступність вищої освіти за кордоном, слабку позитивну освітню й наукову репутацію багатьох вишів, ослаблення їх зв'язків з потенційними роботодавцями, замовниками кадрів, невідповідність матеріальнотехнічного забезпечення закладів вищої освіти тому, що демонструють зарубіжні університети, недостатній рівень мотивації керівних і науково-педагогічних кадрів вищої школи до активної діяльності із забезпечення якості освітніх і навчальних програм, неусвідомлений профорієнтаційний вибір абітурієнта та інші чинники.

Отже, цьогоріч 30 закладів вищої освіти державної форми власності (без урахування їхніх структурних підрозділів) запропонували абітурієнтам першого курсу освітнього ступеню "Бакалавр” навчання за спеціальністю 029․․ Свій “бакалаврський вибір" на користь фаху станом на 01.09.2018 зробили майже 400 осіб (денна форма навчання). Прості математичні розрахунки, виконані з посиланням на відносну пропорцію “виші-кількість першокурсників", уже дозволяють зробити певні висновки. Але про все по порядку.

Посилаючись на дані Сдиної державної системи освіти, найбільшою пропозицією бюджетних місць - 121, і кількістю варіантів освітніх програм - 4, відзначилися столичні виші. Йдеться про Київський національний університет культури і мистецтв (далі КНУКіМ), Національний авіаційний університет, Національний педагогічний університет імені М.П. Драгоманова, Національний транспортний університет, Таврійський національний університет ім. В.І. Вернадського, Київський університет ім. Бориса Грінченка та Державний університет телекомунікацій. Тож конкуренція достойних поміж собою була доволі жорсткою.

Лідером за кількістю поданих заяв на денну форму навчання став КНУКіМ - 380, найвищий конкурсний бал - 170,45, “дістався” абітурієнтам Національного педагогічного університету ім. М.П. Драгоманова, а найбільший конкурс на одне бюджетне місце 9,8 осіб, склався в Державному університеті телекомунікацій. Усього ж бакалаврами І курсу денної форми навчання за спеціальністю 029 "Інформаційна, бібліотечна та архівна справа" столичних закладів вищої освіти стали 149 осіб. Із них - 96 осіб (або 64\%) бюджетної і 53 особи (36\%) контрактної форм фінансування. За результатами вступної кампанії 2018 р. найпривабливішими вишами для абітурієнтів виявилися КНУКіМ (набір на I курс -66 осіб) і Державний університет телекомунікацій (35 осіб), до яких сукупно вступила 101 особа, або ж майже 70\% від загальної кількості тих, хто обрав столичні виші за фахом 029.

Розуміючи умовність цих показників і їх залежність від бюджетної вступної пропозиції, різних кон'юнктурних і традиційний моментів у кожному конкретному випадку та багатьох інших чинників, зауважимо, що пропоновані абітурієнтам освітні програми на тлі потужності промоцій їх вишами значною мірою стали визначальними. Тож заклади, які водночас відзначилися кількістю поданих заяв і найвищим конкурсом, пропонували такі освітні програми: “Документознавство та інформаційна діяльність” (Державний університет телекомунікацій, Національний авіаційний університет), “Інформаційна аналітика та зв’ язки з громадськістю” (Державний університет телекомунікацій).

Окремі заклади вищої освіти, до прикладу Київський університет ім. Бориса Грінченка, КНУКіМ, вказали однойменні зі спеціальністю 029 освітні програми, а Національний педагогічний університет ім. М.П. Драгоманова й Національний транспортний університет не стали взагалі заявляти про освітні програми 3 “Інформаційної, бібліотечної та архівної справи”. Деякі з них вирішили конкретизувати 
зміст цієї програми, вказавши при цьому можливі спеціалізації за фахом. Так на ринку освітніх послуг вчинив КНУКіМ, ухваливши декілька з них - інформаційна аналітика; документознавство, менеджмент органів державної влади та управління; менеджмент бібліотечно-інформаційної діяльності.

Не позбавлена позитивного змісту картина вступної кампанії на спеціальність 029 у регіонах. Незалежно від адресного розміщення замовника на навчання за кошт державного бюджету на спеціальність 029 (освітній ступінь - бакалавр) на рівні регіонів було запропоновано 149 місць, з яких лише 121 стали в нагоді вступникам, тобто $81 \%$. При цьому майже стільки ж (135 осіб) зголосилися сплачувати за навчання власним коштом, що демонструє затребуваність фаху в абітурієнтів. Найбільше таких бажаючих виявилося в Національному університеті “Львівська політехніка" (33 особи), Національному аерокосмічному університеті "XАI" ім. М.Є. Жуковського (18 осіб), Національному університеті “Острозька академія" (11 осіб) та Кременчуцькому національному університеті ім. Михайла Остроградського (11 осіб). За абсолютними кількісними показниками у регіонах лідерами за набором на спеціальність стали Національний університет "Львівська політехніка" (43 особи), Національний аерокосмічний університет "XАI” ім. М.С. Жуковського (24 особи), Тернопільський національний економічний університет (20 осіб), Івано-Франківський національний технічний університет нафти і газу (18 осіб), Національний університет “Острозька академія" (18 осіб). Тож позитивним є факт наявності і кількість тих, хто згодився здобувати освіту коштом фізичних осіб. Тому говорити про відсутність перспектив фаху зарано, проте необхідно докласти багато зусиль для переформатування його звучання й обгрунтованого збагачення змістового наповнення.

Ми виявляємо також, що із 23 регіональних закладів вищої освіти 13 є таких, що змогли зарахувати на I курс бакалаврату спеціальності "Інформаційна, бібліотечна та архівна справа” від 1 до 9 студентів. Прогнозовано згодом деякі з них можуть відмовитися від фаху, що є природнім явищем в умовах жорсткої конкуренції на освітньому ринку. Це призведе до скорочення науково-педагогічного персоналу вишів та інших наслідків.

Найчастіше регіональні виші пропонували документознавчі й інформаційні освітні програми під різними назвами: “Документознавство та інформаційна діяльність” (Одеський національний політехнічний університет, Тернопільський національний економічний університет, Донецький національний університет ім. В. Стуса, Кременчуцький національний університет ім. Михайла Остроградського, Рівненський державний гуманітарний університет, Полтавський національний технічний університет імені Юрія Кондратюка), “Документаційне забезпечення управління та інформаційноаналітична діяльність” (Східноєвропейський національний університет ім. Лесі Українки), “Інформаційна діяльність” (Чернівецький національний університет імені Юрія Федьковича, Луганський національний університет імені Тараса Шевченка), “Управління інформаційними комунікаціями” (Національний університет водного господарства та природокористування), “Інформаційна справа” (Запорізький національний університет). Офіційно не заявили про свої освітні програми лише 5 закладів: Національний аерокосмічний університет "XАI" ім. М.С. Жуковського, Івано-Франківський національний технічний університет нафти і газу, Українська академія друкарства, Східноукраїнський національний університет імені Тараса Шевченка і Національна металургійна академія. Ще 6 вишів презентували освітні програми за назвою спеціальності (Національний університет “Львівська політехніка", Львівський національний університет ім. І.Я. Франка, Національний університет “Острозька академія”, Центральноукраїнський національний технічний університет, Маріупольський державний університет, Мукачівський державний університет). 
Окремо слід відзначити пропозиції Рівненського державного гуманітарного університету, що оголосив прийом на навчання абітурієнтів за двома освітніми програмами традиційного звучання - “Документознавство та інформаційна діяльність”, “Книгознавство, бібліотекознавство і бібліографознавство”. Дещо модернізований підхід до вибору освітньої програми продемонструвала Харківська державна академія культури, намагаючись акцентовано заявити в одній назві про три компоненти спеціальності, якто "Інформаційно-бібліотечний менеджмент, інформаційно-документні системи та цифрові архіви”. I, нарешті, єдиним навчальним закладом, що оголосив набір абітурієнтів на бакалаврат за програмою "Архівна справа та документознавство” в межах спеціальності 029 "Інформаційна, бібліотечна та архівна справа”, став Запорізький національний університет. Між іншим, цього не стали робити ті заклади, які традиційно декларували архівну освіту в межах історичної спеціальності. Тож 2018 р. вступникам до вишів на освітні програми бакалаврату фактично навіть не пропонувався архівний складник спеціальності 029 “Інформаційна, бібліотечна та архівна справа” чи відповідна спеціалізація в межах 032 “Історія, археологія”.

На довершення статистичної картини і маргінальних замальовок до неї констатуємо, нинішня вступна кампанія укотре продемонструвала тенденцію останніх років - заочна форма навчання відходить у минуле. Лише поодинокі заяви від абітурієнтів i, як наслідок, так само невеликий студентський контингент для навчання без відриву від виробництва. Загалом же, порівняно з 2017 р., цьогорічний вступ до вишів відзначився зростанням кількості бажаючих навчатися за спеціальністю 029 "Інформаційна, бібліотечна та архівна справа", проте не настільки, аби говорити про існування стабільної, а не ситуативної, позитивної динаміки іiі розвитку. Повторимося, важливим моментом водночас $\epsilon$ наявність і кількість тих, хто згодився здобувати освіту коштом фізичних осіб. Говорити про відсугність перспектив фаху, справді, зарано, проте необхідно докласти значних зусиль для оновленого його звучання й обгрунтованого збагачення змістового наповнення.

А тепер, відійшовши від проміжних статистичних міркувань, дозволимо собі зробити декілька висновків стосовно перспектив розвитку архівної освіти в Україні. Успіх будь-якої справи починається з усвідомлення декількох моментів. По-перше, необхідно точно розуміти мету реформування архівної освіти, а також розв'язання супутніх сприятливих цьому завдань, що стануть основою її успішної реалізації. Дослідники неодноразово ділилися з професійною спільнотою роздумами про головну мету реформ архівної освіти, суть якої полягає в тому, аби підготувати фахівця, котрий вмітиме застосувати знання практично, а його компетентності відповідали б організаційним, виробничим, економічним, науково-дослідним, іміджевим, комунікаційним потребам сучасних архівів (Бездрабко, 2017; Палієнко, 2015а; Палієнко, 2016). Не тлумачачи необхідні характеристики як відокремлені сутності, у загальному ми розуміємо, що наразі архіви потребують не "універсального дилетанта", а глибоко обізнаного, в першу чергу, 3 архівними технологіями фахівця, здатного працювати з традиційними документами будьякої епохи та найрізноманітніших зовнішніх і внутрішніх характеристик, а також спроможного зорієнтуватися на рівні користувача й дослідника 3 особливостями функціонування інформації в е-середовищі, вправно оперуючи інформаційними технологіями. Вимоги до компетентностей архівіста не $є$ застиглим явищем, постійно змінюються, творяться у відповідь на виклик часу. Визначення кола компетентностей архівіста $є$ початком того, ким він мусить бути, надовго чи ні.

Проте просто твердити про компетентності архівіста і вимоги поточного моменту це використання фрагмента, а не цілісного представлення проблеми. Професіоналізм архівіста потребує належної “інфраструктури”, яка діалектично впливає й визначає його рівень. Ідеться про сучасне матеріально-технічне забезпечення галузі та фінансову 
підтримку з будь-яких джерел широкого діапазону діяльності архівних установ іїх трудових ресурсів. Це потребує відповідального ставлення держави, суспільства до архівної справи, розвитку міжінституційного продуктивного діалогу усіх причетних до підготовки архівістів, архівів, громадських об'єднань, професійних асоціацій, об'єднань, загалом підтримки фахової комунікації тощо. Власне матеріально-технічні й фінансові галузеві ресурси є другою потужною умовою реформування архівної освіти. Інакше всі зусилля педагогів вищої школи виявляться марними. По-третє, всі плани трансформувати архівну освіту й наповнити ії новим змістом можуть виявитися нездійсненними без відповідної нормативно-правової бази освітньої діяльності. Ідеться, в першу чергу, про державні стандарти вищої освіти, зокрема спеціальності 029 "Інформаційна, бібліотечна та архівна справа" (бакалаврський, магістерський освітні ступені), які є базовим документом для реалізації освітніх програм з архівістики навчальними закладами. Хоча кожен із них через гарантовану державою автономію самостійно визначається зі змістовим наповненням освітніх програм, утім дуже важливим моментом є уникнення суб'єктивного підходу, нехтування узгодженості цього процесу з нагальними потребами архівної справи.

I, нарешті, за цим маємо сказати про четверту умову успішної реалізації задуманого реформаторами архівної освіти в Україні. Це наявність кадрів, хто зможе залучати й використовувати різнопланові економічні, технічні, технологічні, наукові, інформаційні, комунікативно-стратегічні ресурси задля вирішення актуальних завдань галузі. Ми не можемо відмовитися від відповідальності перед архівістами й самоусунутися від розв'язання кадрової проблеми архівної сфери, яка безпосередньо пов'язана з вищою та післядипломною освітою. Чимало програм ії розвитку, що були схвалені й затверджені останніми десятиріччями, нарешті мають стати документами з реальним дієвим втіленням ідей. Власне, й самими системними реформами мають займатися професіонали, здатні не тільки до продукування ідей й загальних просторікувань, але й рішучих антикризових управлінських дій, орієнтованих на позитивний результат і досягнення цілей.

Наразі можемо говорити про те, що останніми роками архівна освіта знову стала об’єктом широких наукових дискусій і насправді поодиноких заходів, спрямованих на її підтримку. Як зробити фах конкурентноздатним, на наш погляд, розуміють усі дискутанти. Проте без системного менеджменту й різнопланової (соціальної, матеріальної, фінансової, технічної) підтримки й грошового забезпечення на державному рівні в першу чергу працівника архівної установи важко досягти бажаного результату. Настав час рішучої підтримки ентузіастів-архівістів, котрі, безперечно, демонструють відданість справі й забезпечують їй завтрашній день. Вишам, причетним до спеціальності 029 “Інформаційна, бібліотечна та архівна справа”, залишається об'єднати зусилля заради творення умов, що передують і забезпечують майбутнє архівної освіти.

Маючи апробований десятиріччями вітчизняний і зарубіжний успішний досвід підготовки архівістів (Палієнко, 2015b), варто його вивчити, зробити тяглим у часі чи запозичити найважливіше для створення оптимальної моделі підготовки спеціаліста. Ідеться не тільки про новаційно скомпоновану, модернізовану організацію навчального процесу у вищій школі, його ідеологічний базис і рамку кваліфікацій, раціонально обгрунтований вибір дисциплін для студентів в аудиторії та грунтовну практичну підготовку в архівах, варіативні можливості післядипломної освіти, підвищення кваліфікації, стажування, різні форми навчання, широку наукову комунікацію здобувачів освіти тощо, але й сучасне інструментальне мислення об'єкта освітньої діяльності, майбутнього архівіста, що виражає логіку інтеграції традицій, новацій, продукує цілісність і чітке розуміння результату. Перспективи за ступеневою освітою, варіативністю освітніх програм у вищій школі, що тяжіють до класичного академізму й технологічних практик, післядипломною освітою, дистантною формою організації стажування, перепідготовки 
кадрів, продуктивним союзом навчальних закладів і архівних установ, фаховою комунікацією і менеджерами, здатними на різних рівнях забезпечити ці процеси.

${ }^{1}$ Тут і далі статистичні дані подано станом на 01.09.2018 року згідно з Сдиною державною електронною базою з питань освіти (Див.: URL: Єдина державна електронна база 3 питань освіти. Статистика // https:// vstup.edbo.gov.ua/ (дата звернення: 25 вересня 2018)

\section{Лiтература:}

Археографія, 1995 - Археографія: програма курсу / Уклад. В.С. Шандра; за заг. ред. Л.М. Гордієнка. Київ: КДІК, 1995. 10 с.

Архіви зарубіжних країн, 1995 - Архіви зарубіжних країн: навчальна програма курсу / Уклад. Н.І. Гончарова. Київ: КДІК, 1995. 14 с.

Архівні технології, 1997 - Архівні технології: програма виробничої практики студентів III курсу факультету документознавства та інформаційної діяльності (спеціалізація “Документознавець-архівіст”) / Уклад. В.В. Болдирєв. Київ: КДУКМ, 1997. 20 с.

Бездрабко, 2017 -Бездрабко В.В. Архівна освіта в Україні: традиції й тенденції// Український історичний журнал. 2017. № 3. С. 129-147.

Гончарова, 1999 - Гончарова Н. Інформаційний менеджмент та підготовка фахівців-архівознавців // Студії з архівної справи та документознавства. 1999. Т. 4. С.64-70.

Державні і відомчі архіви України, 1995 - Державні і відомчі архіви України: навчальна програма курсу / Уклад. Н.І. Гончарова. Київ: КДІК, 1995. 21 с.

Довбищенко, 1999 - Довбищенко М. До питання про нові напрями викладацької роботи на кафедрі архівознавства Київського університету культури і мистецтв // Студії з архівної справи та документознавства. 1999. T. 4. C.62-64

Економіка і менеджмент в архівній справі, 2000 - Економіка і менеджмент в архівній справі: програма виробничої практики студентів IV курсу факультету документних комунікацій та міжнародної інформації (спеціалізація “Документознавець-архівіст”) / Уклад. В.В. Болдирєв, Н.І. Гончарова. Київ: КНУКіМ, 2000. 22 с.

Сдина державна електронна база з питань освіти, 2018 - Сдина державна електронна база $з$ питань освіти. Статистика URL: https://vstup.edbo.gov.ua/ (дата звернення: 25 вересня 2018)

Історія і організація архівної справи, 1998 - Історія і організація архівної справи: програма курсу / Уклад. В.В. Болдирєв, Т.А. Гирявец. Київ: КДІК, 1998. 21 с. Історія і організація діловодства, 1992 - Історія і організація діловодства: програма курсу / Уклад. Н.І. Гончарова. Київ: КДІК, 1992.8 с.

Калакура, 2013 - Калакура Я. Наукова школа архівістів та археографів Університету св. Володимира // Вісник Київського національного університету ім. Тараса Шевченка. Історія. 2013. Вип. 5 (118). С. 25-30.

Калакура, 2004 - Калакура Я., Щербак М. Центр архівістики та джерелознавства в Київському університеті // Студії з архівної справи та документознавства. 2004. Т. 12. С. 156-161.

Калакура, 2008 - Калакура Я.С. Архівознавчий осередок шевченківського університету // Архіви України. 2008. С. 158-169.

Калакура, 2002 - Калакура Я.С. Інформатика в системі архівної освіти (з досвіду Київського національного університету імені Тараса Шевченка) // Архівознавство. Археографія. Джерелознавство. Вип. 5. Київ, 2002. С. 141-145.

Калакура, 2000 - Калакура Я.С. Історико-архівознавча школа Київського національного університету імені Тараса Шевченка // Архівознавство. Археографія. Джерелознавство. Вип. 2. Київ, 2000. С. 8-19.

Калакура, 1999 - Калакура Я.С. Сучасне архівознавство у Шевченківському університеті // Студії 3 архівної справи та документознавства. 1999. Т. 4. С. 58-61.

Кінофотодокументи, 1995 - Кінофотодокументи: навчальна програма курсу / Уклад. Н.М. Солончак. Київ: КДІК, 1995. 6 с.

Корнєєв, 2016 - Корнєєв В.М. Соціальнокомунікаційний підхід в українській науці: дис. ... докт. наук із соц. ком.: 27.00.01. Київ, 2016. 451 с.

Короткий російсько-український словник архівних термінів, 1993 - Короткий російсько-український словник архівних термінів / Упоряд. В.В. Болдирєв, Л.М. Гордієнко. Київ: КДІК, [1993]. 16 с.

Маковська, 2002 - Маковська Н. Професійна архівна освіти в Україні: моделі, імідж, перспективи // Архіви України. 2002. № 1/3. С. 46-54.

Матяш, 1998 - Матяш І., Калакура Я., Лозицький В., Селіверстова К. Концепція підготовки та післядипломної освіти кадрів для архівних установ України (проект) // Студії з архівної справи та документознавства. 1998. Т.3. С. 17-24.

Матяш, 2000 - Матяш I. Архівна наука і освіта в Україні 1920-1930-х років. Київ, 2000. 592 с.

Палієнко, 2015a - Палієнко М.Г. Архівіст XXI ст. - історик-ерудит чи інформаційний менеджер: виклик професії // Архівна наука і освіта в незалежній Україні, (Київ, 24 листопада 2015 р.): Шістнадцяті джерелознавчі читання. Київ: [б. в.], 2015. С. 10-12.

Палієнко, 2015b - Палієнко М.Г. Історичні традиції та сучасні тенденції розвитку європейської і американської моделі архівної освіти // Архіви України. 2015. № 3. С. 35-60. 
Палієнко, 2016 - Палієнко М.Г. Архівіст інформаційного суспільства: проблеми модернізації системи професійної освіти // Вісник Київського національного університету ім. Тараса Шевченка. Серія Історія. 2016. Вип. 3 (130). С. 57-62.

Про затвердження переліку галузей знань і спеціальностей, за якими здійснюється підготовка здобувачів вищої освіти, 2015 - Про затвердження переліку галузей знань і спеціальностей, за якими здійснюється підготовка здобувачів вищої освіти: постанова Кабінету Міністрів України № 266 від 29.04.2015 p. URL: http://osvita.ua/legislation/Vishya osvita/46971/ - [Заголовок з екрану]

Проекти стандартів вищої освіти, 2015 - Проекти стандартів вищої освіти. URL: http://mon.gov.ua/ activity/education/reforma-osviti/naukovo-metodichna-rada-ministerstva/proekti-standartiv-vishhoyi-osviti.html - (дата звернення: 25 вересня 2018)

Спеціальні історичні дисципліни, 1994 - Спеціальні історичні дисципліни: навчальна програма для студентів І-ІІ курсів / Уклад. В.В. Болдирєв; за заг. ред. Л.М. Гордієнка. Київ: КДІК, 1994. 14 с.

Створення документів та організація роботи з ними, 1997 - Створення документів та організація роботи з ними: програма виробничої практики студентів II курсу кваліфікації “«Документознавець-архівіст” / Уклад. Н.І. Гончарова, О.В. Денисенко. Київ: КДУКМ, 1997. 14 с.

Терно, 1998 - Терно В., Гончарова Н. Проблеми професійної підготовки спеціалістів з архівної справи у рамках спеціальності “Документознавство та інформаційна діяльність” // Студії з архівної справи та документознавства. 1998. Т.3. С.25-27.

Хорхордина, 2001 - Хорхордина Т.И. Наука об архивах и проблемы исторического образования // Архівознавство. Археографія. Джерелознавство: міжвідомчий наук. зб. Київ, 2001. Вип. 4. С. 267

International Standard Classification of Occupations, 2008 - International Standard Classification of Occupations: structure, group definitions and correspondence tables: ISCO-08. Geneva, 2008. Vol. 1. 433 p.

\section{References:}

Arheohrafiya, 1995 - Arheohrafiya: prohrama kursu [Archeography: course program] / Uklad. V.S. Shandra; za zah. red. L.M. Hordiyenka. Kyiv: KDIK, 1995. 10 s.

Arhivy zarubizhnyh krain, 1995 - Arhivy zarubizhnyh krain: navchalna prohrama kursu [Archives of foreign countries: curriculum of the course] / Uklad. N.I. Honcharova. Kyiv: KDIK, 1995. $14 \mathrm{~s}$.

Arhivni tehnolohiyi, 1997 - Arhivni tehnolohiyi: prohrama vyrobnychoyi praktyky studentiv III kursu fakultetu dokumentoznavstva ta informatsiynoyi diyalnosti (spetsializatsiya "Dokumentoznavets-arhivist") [Archival technologies: the program of industrial practice of the third year students of the Faculty of Documentation and Information Activity] / Uklad. V.V. Boldyryev. Kyiv: KDUKM, 1997. 20 s.

Bezdrabko, 2017 - Bezdrabko V.V. Arhivna osvita v Ukraini: tradytsiyi i tendentsiyi [Archive education in Ukraine: traditions and trends] // Ukrainskyi istorychnyi zhurnal. 2017. № 3. S. 129-147.

Honcharova, 1999 - Honcharova N. Informatsiynyy menedzhment ta pidhotovka fakhivtsivarkhivoznavtsiv [Information management and training of archivists] // Studiyi z arkhivnoi spravy ta dokumentoznavstva. 1999. T. 4. S.64-70.

Derzhavni i vidomchi arkhivy Ukrayiny, 1995 - Derzhavni i vidomchi arkhivy Ukrayiny: navchalna prohrama kursu [State and departmental archives of Ukraine: curriculum of the course] / Uklad. N.I. Honcharova. Kyiv: KDIK, 1995.21 s.

Dovbyshchenko, 1999 - Dovbyshchenko M. Do pytannya pro novi napryamy vykladatskoyi roboty na kafedri arkhivoznavstva Kyivskoho universytetu kultury i mystetstv [On the issue of new directions of teaching at the Department of Archival Studies of the Kyiv University of Culture and Arts] // Studiyi z arkhivnoi spravy ta dokumentoznavstva. 1999. T. 4. S.62-64.

Ekonomika i menedzhment v arhivniy spravi, 2000 - Ekonomika i menedzhment v arhivniy spravi: prohrama vyrobnychoyi praktyky studentiv IV kursu fakultetu dokumentnykh komunikatsiy ta mizhnarodnoyi informatsiyi (spetsializatsiya "Dokumentoznavets-arhivist") [Economics and Management in Archival Affairs: the program of industrial practice of the 4-th year students of the Faculty of Document Communications and International Information]/ Uklad. V.V. Boldyryev, N.I. Honcharova. Kyiv: KNUKiM, 2000. 22 s.

Yedyna derzhavna elektronna baza z pytan osvity, 2018 - Yedyna derzhavna elektronna baza z pytan osvity. Statystyka [Unified state electronic educational base, 2018]. URL: https://vstup.edbo.gov.ua/ (data zvernennya: 25 veresnya 2018)

Istoriya i orhanizatsiya arkhivnoyi spravy, 1998 - Istoriya i orhanizatsiya arkhivnoyi spravy: prohrama kursu [The history and organization of office work: the program of the course] / Uklad. V.V. Boldyryev, T.A. Hyryavets. Kyiv: KDIK, 1998. $21 \mathrm{~s}$.

Istoriya i orhanizatsiya dilovodstva, 1992 - Istoriya i orhanizatsiya dilovodstva: prohrama kursu [Scientific School of Archivists and Archaeographers of the University of St. Volodymyr] / Uklad. N.I. Honcharova. Kyiv: KDIK, 1992. 8 s.

Kalakura, 2013 - Kalakura Ya. Naukova shkola arkhivistiv ta arkheohrafiv Universytetu sv. Volodymyra [Scientific School of Archivists and Archaeographers of the University of St. Volodymyr] // Visnyk Kyivskoho natsionalnoho universytetu im. Tarasa Shevchenka. Istoriya. 2013. Vyp. 5 (118). S. 25-30.

Kalakura, 2004 - Kalakura Ya., Shcherbak M. Tsentr arkhivistyky ta dzhereloznavstva v Kyivskomu universyteti [Center for Archival Studies and Source Studies at Kyiv University] // Studiyi z arkhivnoi spravy ta dokumentoznavstva. 2004. T. 12. S. 156-161. 
Kalakura, 2008 - Kalakura Ya.S. Arhivoznavchyy oseredok shevchenkivskoho universytetu [Archival Research Center of Shevchenko University] // Arkhivy Ukrayiny. 2008. S. 158-169.

Kalakura, 2002 - Kalakura Ya.S. Informatyka v systemi arkhivnoyi osvity (z dosvidu Kyyivskoho natsionalnoho universytetu imeni Tarasa Shevchenka) [Informatics in the system of archival education (from the experience of Kyiv National Taras Shevchenko University)] // Arhivoznavstvo. Arheohrafiya. Dzhereloznavstvo. Vyp. 5. Kyiv, 2002. S. 141-145.

Kalakura, 2000 - Kalakura Ya.S. Istoryko-arhivoznavcha shkola Kyivskoho natsionalnoho universytetu imeni Tarasa Shevchenka [Historical and archival school of Kyiv National Taras Shevchenko University] // Arhivoznavstvo. Arheohrafiya. Dzhereloznavstvo. Vyp. 2. Kyiv, 2000. S. 8-19.

Kalakura, 1999 - Kalakura Ya.S. Suchasne arkhivoznavstvo u Shevchenkivskomu universyteti [Modern archival studies at Shevchenko University] // Studiyi z arkhivnoi spravy ta dokumentoznavstva. 1999. T. 4. S. 58-61.

Kinofotodokumenty, 1995 - Kinofotodokumenty: navchalna prohrama kursu [Cinematographic documents: curriculum of the course]/Uklad. N.M. Solonchak. Kyiv: KDIK, 1995. 6 s.

Kornyeyev, 2016 - Kornyeyev V.M. Sotsialnokomunikatsiynyy pidkhid v ukrayinskiy nautsi [Social Communication Approach in Ukrainian Science]: dys. ... doct. nauk iz sotsialnykh komunikatsiy: 27.00.01. Kyiv, 2016.451 s.

Korotkyy rosiysko-ukrayinskyy slovnyk arkhivnykh terminiv, 1993 - Korotkyy rosiysko-ukrayinskyy slovnyk arkhivnykh terminiv [A short Russian-Ukrainian dictionary of archival terms Кінофотодокументи: навчальна програма курсу] / Uporyad. V.V. Boldyryev, L.M. Hordiyenko. Kyiv: KDIK, [1993]. 16 s.

Makovska, 2002 - Makovska N. Profesiyna arkhivna osvity v Ukrayini: modeli, imidzh, perspektyvy [Professional archive of education in Ukraine: model, image, perspectives] // Arkhivy Ukrayiny. 2002. № 1/3. S. 46-54.

Matyash, 1998 - Matyash I., Kalakura YA., Lozytskyy V., Seliverstova K. Kontseptsiya pidhotovky ta pislyadyplomnoyi osvity kadriv dlya arkhivnykh ustanov Ukrayiny (proekt) [Concept of training and postgraduate education of personnel for archival institutions of Ukraine (project)] // Studiyi z arkhivnoi spravy ta dokumentoznavstva. 1998. T.3. S. 17-24.

Matyash, 2000 - Matyash I. Arhivna nauka i osvita v Ukrayini 1920-1930-kh rokiv [Archival Science and Education in Ukraine 1920-1930s.]. Kyiv, 2000. 592 s.

Paliyenko, 2015a - Paliyenko M.H. Arhivist XXI st. - istoryk-erudyt chy informatsiynyy menedzher: vyklyk profesiyi [Archivist XXI c - a historian-erudite or information manager: a challenge to the profession] // Arhivna nauka i osvita v nezalezhniy Ukrayini, (Kyiv, 24 lystopada 2015 r.): Shistnadtsyati dzhereloznavchi chytannya. Kyiv: [b. v.], 2015. S. 10-12.

Paliyenko, 2015b - Paliyenko M.H. Istorychni tradytsiyi ta suchasni tendentsiyi rozvytku yevropeyskoyi i amerykanskoyi modeli arkhivnoyi osvity [Historical traditions and modern tendencies of development of the European and American model of archival education] // Arkhivy Ukrayiny. 2015. № 3. S. 35-60.

Paliyenko, 2016 - Paliyenko M.H. Arhivist informatsiynoho suspilstva: problemy modernizatsiyi systemy profesiynoyi osvity [Archivist of the Information Society: Problems of Modernization of the Professional Education System] // Visnyk Kyivskoho natsionalnoho universytetu im. Tarasa Shevchenka. Seriya Istoriya. 2016. Vyp. 3 (130). S. 57-62.

Pro zatverdzhennya pereliku haluzey znan i spetsialnostey, za yakymy zdiysnyuyetsya pidhotovka zdobuvachiv vyshchoyi osvity, 2015 - Pro zatverdzhennya pereliku haluzey znan i spetsialnostey, za yakymy zdiysnyuyetsya pidhotovka zdobuvachiv vyshchoyi osvity: postanova Kabinetu Ministriv Ukrayiny [On Approval of the List of Fields of Knowledge and Specialties under which Higher Education Institutions are Prepared, 2015] № 266 vid 29.04.2015 r. URL: http://osvita.ua/legislation/Vishya osvita/46971/ - [Zaholovok z ekranu]

Proekty standartiv vyshchoyi osvity, 2015 - Proekty standartiv vyshchoyi osvity [Projects of Higher Education Standards, 2015]. URL: http://mon.gov.ua/activity/education/reforma-osviti/naukovo-metodichna-radaministerstva/proekti-standartiv-vishhoyi-osviti.html - (data zvernennya: 25 veresnya 2018)

Spetsialni istorychni dystsypliny, 1994 - Spetsialni istorychni dystsypliny: navchalna prohrama dlya studentiv I-II kursiv [Special Historical Disciplines: A curriculum for students of the I-II year] / Uklad. V.V. Boldyryev; za zah. red. L.M. Hordiyenka. Kyiv: KDIK, 1994. 14 s.

Stvorennya dokumentiv ta orhanizatsiya roboty z nymy, 1997 - Stvorennya dokumentiv ta orhanizatsiya roboty z nymy: prohrama vyrobnychoyi praktyky studentiv II kursu kvalifikatsiyi "Dokumentoznavets-arkhivist" [Creation of documents and organization of work with them: program of industrial practice of students of the 2 year] / Uklad. N.I. Honcharova, O.V. Denysenko. Kyiv: KDUKM, 1997. 14 s.

Terno, 1998 - Terno V., Honcharova N. Problemy profesiynoyi pidhotovky spetsialistiv z arhivnoyi spravy u ramkakh spetsialnosti "Dokumentoznavstvo ta informatsiyna diyalnist" [Problems of professional training of specialists in archives in the specialty "Documentation and Information Activity"] // Studiyi z arkhivnoi spravy ta dokumentoznavstva. 1998. T.3. S.25-27.

Khorkhordyna, 2001 - Khorkhordyna T.Y. Nauka ob arkhyvakh y problemy ystorycheskoho obrazovanyya [The science of archives and the problems of historical education] // Arhivoznavstvo. Arheohrafiya. Dzhereloznavstvo: mizhvidomchyy nauk. zb. Kyiv, 2001. Vyp. 4. S. 267

International Standard Classification of Occupations, 2008 - International Standard Classification of Occupations: structure, group definitions and correspondence tables: ISCO-08. Geneva, 2008. Vol. 1. 433 p.

Отримано 10.10.2018 